\title{
REVIEW
}

\section{Recent genetic discoveries in osteoporosis, sarcopenia and obesity}

\author{
Tomohiko Urano ${ }^{1)}$ and Satoshi Inoue ${ }^{1), 2)}$ \\ 1) Department of Geriatric Medicine, Graduate School of Medicine, The University of Tokyo, Tokyo 113-8655, Japan \\ 2) Department of Anti-Aging Medicine, Graduate School of Medicine, The University of Tokyo, Tokyo 113-8655, Japan
}

\begin{abstract}
Osteoporosis is a skeletal disorder characterized by low bone mineral density (BMD) and an increased susceptibility to fractures. Evidence from genetic studies indicates that BMD, a complex quantitative trait with a normal distribution, is genetically controlled. Genome-wide association studies (GWAS) as well as studies using candidate gene approaches have identified single-nucleotide polymorphisms (SNPs) that are associated with BMD, osteoporosis and osteoporotic fractures. These SNPs have been mapped close to or within genes including those encoding WNT/ $\beta$-catenin signaling proteins. Understanding the genetics of osteoporosis will help to identify novel candidates for diagnostic and therapeutic targets. Genetic factors are also important for the development of sarcopenia, which is characterized by a loss of lean body mass, and obesity, which is characterized by high fat mass. Hence, in this review, we discuss the genetic factors, identified by genetic studies, which regulate the body components related to osteoporosis, sarcopenia, and obesity.
\end{abstract}

Key words: Single nucleotide polymorphism (SNP), Osteoporosis, Sarcopenia, Obesity, GPR98

OSTEOPOROSIS is a skeletal disease characterized by low bone mineral density (BMD) and microarchitectural deterioration of bone tissue, predisposing those with the disease to an increased risk of fractures [1]. Many of these osteoporotic fractures are associated with significant morbidity and mortality not only in developing countries, but also in developed countries [2]. BMD, the primary surrogate marker of osteoporosis and a major predictor of fracture risk, is a complex quantitative trait with a normal distribution in humans. Several twin and family studies have consistently shown that genetic factors account for approximately $50-90 \%$ of the interindividual variation in BMD [3-5]. Modest associations have been reported between BMD variations and genetic polymorphisms in or near some genes $[6,7]$.

In addition to osteoporosis, the loss of skeletal muscle is a common disorder in the elderly [8-10]. This symptom is related to diseases such as sarcopenia, a major skeletal disease characterized by low lean

Submitted Mar. 16, 2015; Accepted Mar.16, 2015 as EJ15-0154

Released online in J-STAGE as advance publication Apr. 11, 2015

Correspondence to: Satoshi Inoue, Department of Geriatric Medicine, Graduate School of Medicine, The University of Tokyo, Tokyo 113-8655, Japan. E-mail: sinoue07@gmail.com body mass, leading to decreased skeletal strength and increased susceptibility to falls and fractures $[9,10]$. As with low BMD, low lean body mass has a strong genetic component, with heritability ranging over $50 \%$ $[11,12]$. However, the specific genes underlying the variation in low lean body mass are largely unknown.

The prevalence of obesity has increased in recent years [13]. Obesity has become one of the most serious health problems, and its occurrence is attributed to the interplay between environmental and genetic factors and obesity-associated genes [14-16]. Over $40 \%$ of the variation in obesity-related phenotypes is estimated to be heritable [14-16]. Genetic studies and knockout mouse models have uncovered new obesity-associated genes $[16,17]$.

In this review, we briefly summarize the current knowledge about the genetic factors that are related to the pathogenesis of osteoporosis, sarcopenia, and obesity.

\section{Genetic variations in estrogen receptor genes and osteoporosis}

Estrogen deficiency is an important risk factor for postmenopausal osteoporosis [18]. The physiological functions of estrogen are modulated largely by two 
estrogen receptors (ESRs), namely ESR1 (ER $\alpha)$ and ESR2 (ER $\beta$ ), encoded by two different genes [19]. ER $\alpha$ mainly mediates the action of estrogen in the bone [20, 21]. In 1995 and 1996, we reported the correlation between BMD and the TA variable number of tandem repeats (VNTR) within the ESR1 promoter region [22] and also between BMD and the IVS1 - 397T > C SNP (rs2234693, detected by PvuII) in ESRI [23]. Thereafter, many other studies also demonstrated the association of the TA VNTR of the ESR1 promoter region, IVS1 397T > C SNP, and IVS1 - 351A > G SNP (rs9340799, detected by $X b a \mathrm{I})$ with BMD [21, 24].

rs2234693 and rs9340799 lie within the introns of ESR1 and are in strong linkage disequilibrium. The SNP alleles $\mathrm{P}$ and $\mathrm{X}$ (characterized by the absence of both restriction sites) as well as alleles $\mathrm{p}$ and $\mathrm{x}$ (indicating the presence of both restriction sites) are strongly associated with each other. Although haplotype $\mathrm{pX}$ was not detected in most of the studies, the haplotype Px was detected at a low frequency, suggesting that linkage disequilibrium is not complete. The $\mathrm{T}>\mathrm{C}$ change at rs2234693 resulted in a potential binding site for the transcription factor myb, followed by in vitro transcriptional changes, indicating that the $\mathrm{T}>\mathrm{C}$ change may alter ESR1 transcription [25].

VNTR polymorphisms in the vicinity of certain gene promoters can have a significant effect on transcriptional regulation [26]. Genetic variation arising from different TA repeat lengths can also affect promoter activity in ESR1. Recently, the SNPs in ESR1 have been shown to be related to susceptibility to osteoporosis not only in studies using a candidate gene approach but also in several GWAS and meta-analyses [27-31].

\section{Regulation of bone metabolism by variations in the $L R P 5$}

The WNT signaling pathway plays an important role in several cellular functions [32]. Studies using Drosophila, Xenopus, and mammalian models have indicated that the WNT signaling pathway is subdivided into three branches: the $\mathrm{WNT} / \beta$-catenin pathway, also called the canonical WNT pathway; the noncanonical WNT-planar cell polarity pathway; and the WNT-calcium pathway. In the canonical WNT pathway, WNT proteins bind Frizzled (FZ) proteins and either LRP5 or LRP6. This results in the inhibition of glycogen synthase kinase 3 (GSK3)-dependent phosphorylation of $\beta$-catenin, followed by the stabilization of $\beta$-catenin. Both genetic and biochemical results have provided evidence indicating that $\mathrm{FZ}$ proteins and either LRP5 or LRP6 function as Wnt receptors.

Fourteen years ago, the $\mathrm{WNT} / \beta$-catenin pathway was shown to regulate bone density through LRP5 [33-36]. In 2001, Gong et al. reported that inactivating mutations in the human LRP5 decreased bone mass and caused an autosomal recessive disorder, osteoporosis-pseudoglioma syndrome [33]. Subsequently, in 2002, Little et al. and Boyden et al. reported that activating mutations in LRP5 led to autosomal dominant high bone mass traits $[34,35]$. Taken together, these data indicate that LRP5 controls bone metabolism in vivo in humans.

In 2004, we first reported that a common SNP in intron 17 of LRP5 was significantly associated with BMD in Japanese postmenopausal women [37]. We have also found that the IVS17 - 1677C > A SNP and the nonsynonymous SNP in exon 18 , caused by an amino acid change of alanine to valine $(3989 \mathrm{C}>\mathrm{T}$, A1330V), were in strong linkage disequilibrium ( ${ }^{\prime}$ $\left.=0.99, \mathrm{r}^{2}=0.98\right)[38]$. We and several other groups have since shown that the A1330V SNP is associated with BMD and incidence of fractures (Table 1) [3951]. These data suggest that the amino acid change at codon 1330 in LRP5 may affect the pathogenesis of osteoporosis through decreasing activity of the WNT/ $\beta$-catenin pathway.

To evaluate the functional significance of the A1330V SNP, we substituted the alanine at codon 1330 in the major-type LRP5 (LRP5-A1330) to valine (LRP5-V1330) [50]. We transfected HEK293T cells with these LRP5 constructs and measured TCF-Lef reporter activity in response to canonical Wnt signaling. The Wnt-accelerated TCF-Lef activity was significantly reduced in the cells containing LRP5-V1330 compared to those containing the major-type allele. These data suggest that the nonsynonymous SNP at codon 1330 may alter the activity of the WNT/ $\beta$ catenin pathway and affect BMD in humans.

Since our first report in 2004, there have been several reports on the association between nonsynonymous LRP5 SNPs and different bone phenotypes, including BMD and osteoporotic fracture [7, 52-55]. These SNPs included 3 nonsynonymous SNPs: Q89R, V667M, and A1330V. In Caucasian populations, the V667M SNP was found to be significantly associated with BMD [52]. To our knowledge, no association studies between the V667M SNP and bone phenotypes 
Table 1 Association studies between the SNPs in the LRP5 gene and bone mineral density (BMD).

\begin{tabular}{|c|c|c|c|}
\hline Study group & Year Journal & Participants & Parameters \\
\hline Urano et al. [37] & 2004 J Bone Miner Metab & Japanese postmenopausal women & Total body BMD \\
\hline Mizuguchi et al. [39] & 2004 J Hum Genet & Japanese women (over 50 y.o.) & Lumbar BMD \\
\hline Koay et al. [40] & 2004 J Bone Miner Res & $\begin{array}{l}\text { Osteoporotic probands and their } \\
\text { families }\end{array}$ & $\begin{array}{l}\text { lumbar spine, femoral neck, and hip } \\
\text { BMD }\end{array}$ \\
\hline Bollerslev et al. [41] & 2005 Bone & Australian elderly women & Femoral neck and trochanter BMD \\
\hline Ferrari et al. [42] & 2005 Bone & Caucasian men & Femoral neck and trochanter BMD \\
\hline vanMeurs et al. [43] & 2006 J Bone Miner Res & Caucasian men (over 55 y.o.) & Lumbar spine and femoral neck BMD \\
\hline Saarinen et al. [44] & 2007 Bone & Finnish young men & Femoral neck and trochanter BMD \\
\hline Xiong et al. [45] & 2007 J Bone Miner Res & Chinese and Caucasian subjects & spine, hip, and ultradistal radius $\mathrm{BMD}$ \\
\hline Ezura et al. [38] & 2007 Bone & Japanese women & Lumbar spine and radial BMD \\
\hline Giroux et al. [46] & 2007 Bone & French-Canadian women & Lumbar spine and femoral neck BMD \\
\hline vanMeurs et al. [47] & 2008 JAMA & $\begin{array}{l}\text { Caucasian in Europe and North } \\
\text { America }\end{array}$ & $\begin{array}{l}\text { Femoral neck BMD and osteoporotic } \\
\text { fractures }\end{array}$ \\
\hline Richards et al. [48] & 2008 Lancet & $\begin{array}{l}\text { Caucasian (Genome-wide } \\
\text { association study) }\end{array}$ & BMD and osteoporotic fractures \\
\hline Agueda L et al. [49] & 2008 J Bone Miner Res & Spanish postmenopausal women & $\begin{array}{l}\text { Lumbar spine, femoral neck BMD } \\
\text { and osteoporotic fracture }\end{array}$ \\
\hline Urano et al. [50] & 2009 Endocr J & Japanese postmenopausal women & Total body BMD \\
\hline Lee et al. [51] & 2009 Rheumatol Int & Meta-analysis & Meta-analysis \\
\hline
\end{tabular}

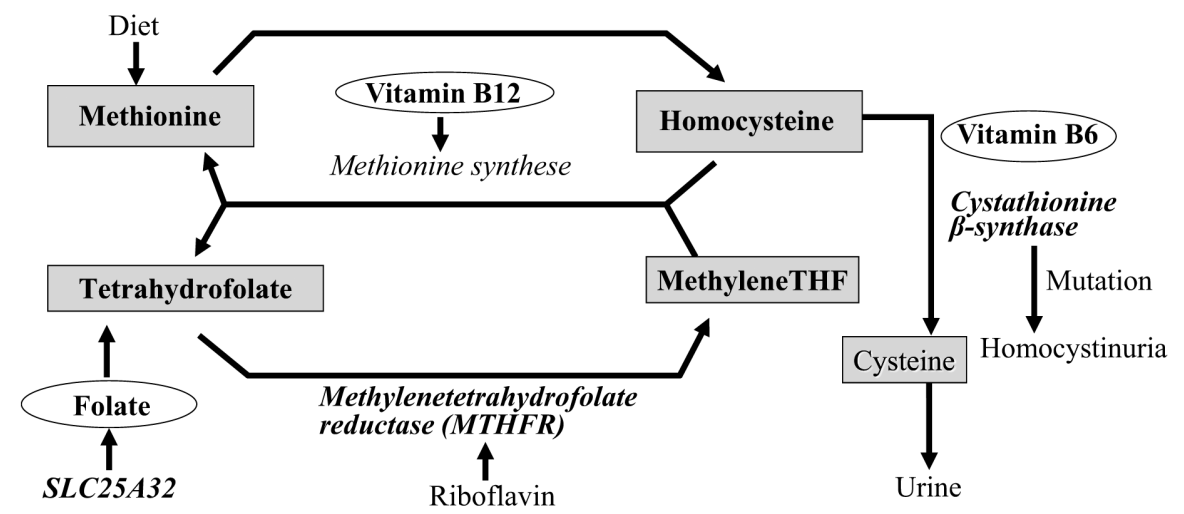

Fig. 1 The metabolism of homocysteine. Homocystinuria is a rare autosomal recessive disease in which the metabolism of homocysteine is severely impaired leading to excessive accumulation of homocysteine in the blood and urine. A common cause of homocystinuria is cystathione- $\beta$-synthase deficiency. THF, tetrahydrofolate.

have been reported in Asian populations. This could be due to the low allele frequency of the V667M SNP in Asian populations. The Q89R SNP has been studied only in Asian populations, most likely because of its low frequency in other ethnic populations. Significant associations between the Q89R SNP and femoral neck BMD were reported in young Korean men [53] and Chinese women [54]. Q89R was also associated with lumbar osteophyte formation in Japanese postmenopausal women [55]. In Korean and Chinese populations, strong linkage disequilibrium was observed between Q89R and A1330V [53, 54]. In our previous study, Q89R and A1330V SNPs were not in significant linkage disequilibrium $\left(\mathrm{D}^{\prime}=0.65, \mathrm{r}^{2}=0.08\right)[38]$.

\section{SNPs in the homocysteine and folate- related genes and fractures}

Several cohort reports indicated that B-vitamins could play protective roles in bone health [56]. Homocystinuria is a rare autosomal recessive disease in which the metabolism of homocysteine is severely impaired, leading to excessive accumulation of homocysteine in the blood and urine (Fig. 1). A common cause of homocystinuria is a cystathione- $\beta$-synthase deficiency. Homocystinuria is characterized by precocious osteoporosis. The major determinant of homocysteine concentration is the biomarker status of the metabolically related folate, vitamin B12, and vita- 
min B6 (Fig. 1). Methylenetetrahydrofolate reductase (MTHFR), an important enzyme in the methionine cycle [57], is involved in the removal of circulating homocysteine. MTHFR lies within a linkage region on chromosome $1 \mathrm{p} 36$ that is associated with the regulation of BMD [58, 59]. A C677T nonsynonymous and functional polymorphism has been identified in exon 4 of MTHFR that results in an alanine to valine change. The T-allele variant (valine type) has a lower MTHFR activity than the wild type (C-allele or alanine type) and is also associated with moderately elevated homocysteine levels [57]. An elevated homocysteine level has been recognized as a significant risk factor for fractures [60-62], independent of age and BMD, because it is caused by abnormal collagen cross-links during bone calcification [63-65]. Clinical evidence regarding the role of the MTHFR C677T polymorphism in BMD remains controversial [66].

We previously reported that in Japanese postmenopausal women, the MTHFR C677T polymorphism alone is a weaker risk factor for future fractures compared to traditional risk factors [67]. However, patients bearing the TT genotype together with low BMD show a higher risk and earlier occurrence of fractures than other groups, indicating that the MTHFR TT genotype may act synergistically with traditional risk factors that lead to fractures. Another report in the Caucasian population showed that the risk of hip fractures increased in the TT group compared with the CC group. Patients bearing the TT genotype showed an increased risk of fractures when their plasma folate levels were low [61]. Lower plasma folate levels led to an increase in the plasma levels of homocysteine. These results suggest a strong association of the effects of the MTHFR C677T polymorphism on homocysteine and bone quality with the risk of fractures.

Folate is known to have an effect on homocysteine metabolism (Fig. 1). We recently analyzed the association between plasma folate levels and fractures [68]. Postmenopausal Japanese women with the lower plasma folate levels had a significantly increased risk of fracture. These data are consistent with previous reports. Folate metabolism is distributed between the cytosolic and mitochondrial compartments. $S L C 25 A 32$ is a transporter that shuttles folate from the cytoplasm into mitochondria [69, 70]. Recently, we identified SNPs in SLC25A32 that are associated with plasma folate levels [68]. We also found that the SNPs in this gene are associated with the incidence of frac- tures. Interestingly, these SNPs were not associated with BMD in this population; however, they may affect the bone quality. Thus, genetic analyses revealed that SLC25A32 is a novel candidate gene associated with folate metabolism and bone fragility.

\section{GWAS related to osteoporosis and osteoporotic fractures}

Although the genetics of osteoporosis have been studied through various association studies by candidate gene approaches, the major susceptibility genes and the molecular mechanisms responsible for osteoporosis and osteoporotic fracture remain unclear. In contrast to the candidate gene approach, GWAS is an unbiased approach that involves scanning the entire genome to identify novel genes with modest effects on complex diseases/traits [6-7]. Over the past eight years, a number of GWAS have uncovered novel SNPs associated with complex diseases/traits, including osteoporosis and BMD in Caucasian and Asian populations (Table 2) [30, 31, 48, 71-82].

GWAS for osteoporosis and osteoporotic fractures have identified the following candidate genes in the WNT/ $\beta$-catenin signaling pathway $[27,31,48,73,75$, 76, 80-83]: catenin $\beta 1(C T N N B 1)$, sclerostin (SOST), LRP4, LRP5, GPR177, WNT4, WNT5B, WNT16, dickkopf1 (DKK1), gene for secreted Frizzled-related protein 4 (sFRP4), Jagged 1 (JAG1), MEF2C, and AXIN1. GWAS for osteoporosis have also identified three important factors, namely, RANK, RANKL, and OPG in the bone resorption cycle $[48,72,73]$. Osteoblasts and osteocytes secrete a soluble factor called RANKL [84] that interacts with RANK located on the surface of osteoclast precursor cells, leading to the differentiation and fusion of osteoclastic lineage cells. Osteoblasts and osteocytes also produce a decoy receptor for RANKL called OPG, which inhibits its binding to RANK, thereby impeding the bone resorption cycle.

We also analyzed GWAS of BMD in Japanese postmenopausal women [77, 79]. We showed the association of nonsynonymous SNPs in the WD repeats and SOF1 domain-containing gene (WDSOF1) with BMD [77]. We also identified the association of the SNP in the 3'-flanking region of GPR 98 with BMD and fractures. We then showed the phenotype of Gpr 98 knockout mice and revealed that the GPR98/Gpr98 signaling pathway could be critical in the regulation of BMD and bone fragility through the modulation of RANKL pro- 
Table 2 Genome-wide association studies in bone mineral density and osteoporotic fracture.

\begin{tabular}{|c|c|c|c|c|c|}
\hline Study group & Year & Journal & $\begin{array}{l}\text { Participants in } 1^{\text {st }} \\
\text { screening }\end{array}$ & $\begin{array}{l}\text { Participants in replication } \\
\text { study }\end{array}$ & Identified genes \\
\hline Kiel et al. [71] & 2007 & BMC Med Genet & American Caucasian & - & \\
\hline Richards et al. [48] & 2008 & Lancet & Caucasian twins & $\begin{array}{l}\text { RS, British twins, British } \\
\text { population }\end{array}$ & LRP5, OPG \\
\hline Styrkarsdottir et al. [72] & 2008 & N Engl J Med & Icelandic subjects & $\begin{array}{l}\text { Icelandic, Danish, and } \\
\text { Australian subjects }\end{array}$ & $\begin{array}{l}\text { RANKL, OTB, } \\
\text { ESR1, RANK }\end{array}$ \\
\hline Styrkarsdottir et al. [73] & 2009 & Nat Genet & Icelandic subjects & European descent & $\begin{array}{l}\text { SOST, MARK3, } \\
\text { SP7, RANK }\end{array}$ \\
\hline Xiong et al. [74] & 2009 & Am J Hum Genet & Caucasian in US & $\begin{array}{l}\text { US white and Chinese, } \\
\text { African and FOS data }\end{array}$ & $\begin{array}{l}\text { ADAMTS18, } \\
\text { TGFBR3 }\end{array}$ \\
\hline Cho et al. [75] & 2009 & Nat Genet & Korean subjects & Korean subjects & sFrp4 \\
\hline Rivadeneira et al. [27] & 2009 & Nat Genet & Meta analysis & Meta analysis & $\begin{array}{l}\text { ESR1, GPR177, } \\
\text { MEF2C }\end{array}$ \\
\hline Kung et al. [76] & 2010 & Am J Hum Genet & Asian in Hong Kong & $\begin{array}{l}\text { Asian, Chinese and FOS } \\
\text { and Twins UK data }\end{array}$ & JAG1 \\
\hline Urano et al. [77] & 2010 & Bone & $\begin{array}{l}\text { Japanese postmenopausal } \\
\text { women }\end{array}$ & Japanese women & WDSOF1 \\
\hline Kou et al. [78] & 2010 & PLoS One & Japanese subjects & Japanese subjects & FONG \\
\hline Urano et al. [79] & 2012 & J Clin Endocrinol Metab & $\begin{array}{l}\text { Japanese postmenopausal } \\
\text { women }\end{array}$ & $\begin{array}{l}\text { Japanese women and } \\
\text { FOS data }\end{array}$ & GPR98 \\
\hline Estrada et al. [80] & 2012 & Nat Genet & Meta analysis & Meta analysis & $\begin{array}{l}\text { LRP5, FAM210A, } \\
\text { SLC25A13, DKK1 }\end{array}$ \\
\hline Medina-Gomez et al. [81] & 2012 & PLoS Genet & Meta analysis & Meta analysis & Wnt16 \\
\hline Zheng et al. [82] & 2012 & PLoS Genet & Meta analysis & Meta analysis & Wnt16 \\
\hline Zhang et al. [30] & 2014 & Hum Mol Genet & Meta analysis & Meta analysis & $\begin{array}{l}\text { ESR1, SMOC1, } \\
\text { CLDN14 }\end{array}$ \\
\hline Moayyeri et al. [31] & 2014 & Hum Mol Genet & Meta analysis & Meta analysis & $\begin{array}{l}\text { ESR1, Wnt16, } \\
\text { DKK1, TMEM135 }\end{array}$ \\
\hline
\end{tabular}

duction in osteoblasts [79].

Denosumab is a monoclonal anti-RANKL antibody that inhibits the binding of RANKL to RANK, decreasing osteoclastogenesis and bone resorption of mature osteoclasts. Denosumab is currently used to treat osteoporosis and is a highly effective treatment for osteoporosis [85]. Inhibitors of SOST and DKK1 have been developed and seem to be promising drugs for the treatment of osteoporosis [86]. GPR98/Gpr98 is a member of the G-protein coupled receptor (GPCR) family [79]. The GPCR family represents one of the largest druggable target families in the human genome [87]. The identification of the ligands of GPR98/Gpr98 may be an important step in developing new drugs for osteoporosis. Thus, GWAS will be useful in the design of therapies for as well as the diagnosis of osteoporosis.

\section{GWAS related to sarcopenia and lean mass}

Loss of skeletal muscle function and mass is a major disorder in geriatric medicine and is related to diseases such as sarcopenia, osteoporotic fracture, and frailty
[8-10]. Sarcopenia is a common skeletal disease characterized by low muscle mass, leading to decreased skeletal strength and increased susceptibility to falls and osteoporotic fractures $[9,10]$. Measuring lean body mass by DXA is a good index for the quantity and quality of skeletal muscles [88]. Low lean body mass has a strong genetic component, with heritability ranging over $50 \%[11,12]$. However, the specific genes underlying the variation in low lean body mass are largely unknown. In 2009, Liu et al. reported a GWAS on lean body mass variation, using Affymetrix 500K SNP arrays [89]. In this report, two SNPs within the thyrotropin-releasing hormone receptor gene (TRHR) were significantly associated with low lean body mass. These associations were replicated in three independent samples. Subsequently, several reports have identified the SNPs and genes that are related to the low lean body mass phenotype (Table 3) [89-93].

In 2014, we reported a large-scale association study for low lean body mass using Affymetrix 250K SNP arrays in Japanese postmenopausal women [93]. The association of an SNP (rs12409277) located in the 
Table 3 Genome-wide association studies in lean body mass.

\begin{tabular}{lllll}
\hline Study group & Year Journal & Participants & Parameters & Identified genes \\
\hline Liu et al. [89] & 2009 Am J Hum Genet & Caucasian & Total body lean mass measured by DXA & TRHR \\
Hai et al. [90] & 2012 J Hum Genet & Chinese population & Total body lean mass measured by DXA & gremlin1 \\
Guo et al. [91] & 2013 Hum Genet & $\begin{array}{l}\text { Han Chinese adults and } \\
\text { US Caucasians }\end{array}$ & Appendicular lean mass measured by DXA GLYA \\
Ran et al. [92] & 2014 PLoS One & $\begin{array}{l}\text { Chinese population } \\
\text { Japanese postmenopausal }\end{array}$ & Appendicular lean mass measured by DXA GIMAP1, \\
Urano et al. [93] & 2014 Aging Cell & women & Total lean mass measured by DXA & PRDM16 \\
\hline
\end{tabular}

5'-flanking region of the PRD1-BF-1-RIZ1 homologous domain containing protein 16 gene (PRDM16) was further confirmed in replication study with postmenopausal Japanese women comprised of 1081 subjects. PRDM16 plays an important role in the control of differentiation of the brown fat lineage from a progenitor that expresses myoblast markers [94]. This functional SNP can affect the transcriptional activity and protein-DNA interaction in the promoter/ enhancer region of PRDM16 [93]. Together with previous reports, our results suggest that the amount of PRDM16 could regulate not only brown adipose tissue metabolism, but also white adipose tissue and muscle cell metabolism.

\section{GWAS related to obesity and fat mass}

Obesity is a key feature of metabolic diseases such as type 2 diabetes and cardiovascular disease [13]. Twin and adoption studies have shown that genetic factors play a role in the obesity phenotype $[14,16]$. With the development of high-throughput genotyping techniques and the implementation of GWAS, common variants have been associated with obesity and body mass index (BMI). In 2007, three independent studies identified a strong association between genetic variance within fat mass and obesity-associated gene (FTO) and human obesity [95-97]. Subsequently, replication studies and meta-analysis suggested a positive association between FTO gene polymorphisms and overweight/obesity risk among children, adolescents, and the general population [98]. Moreover, studies in mice and cellular models revealed that the perturbation of FTO enzymatic activity dysregulated genes related to energy metabolism, causing the disruption in the energy and adipose tissue homeostasis [98]. In addition to FTO, GWAS have identified at least 75 obesity susceptibility loci [99-104].

Given the increasing prevalence of obesity and the aging of the population, understanding the factors associated with obesity in old age is critical. Recently, we performed a search for SNPs associated with body fat percentage using GWAS and undertook a concurrent replication study and animal study [105]. Baseline examinations were conducted in 251 (first-stage analysis), 499 (second-stage analysis), and 732 (additional analyses) Japanese postmenopausal women (mean age \pm standard deviation: $66.5 \pm 9.4$ years). In this report, we focused on an SNP of SLC25A24 that showed the lowest significant $P$ value obtained from multiple comparison tests among Japanese postmenopausal women. A significant association was also confirmed between SLC25A24 SNPs and body mass index in the 1482 Japanese postmenopausal women. Compared with wild-type mice, Slc25a24-knockout mice had significantly lower body weights, liver weights and white adipose tissue weights. Adipocyte differentiation and lipid accumulation was inhibited in Slc25a24-knockout adipose tissues and Slc25a24-knockdown adipocytes. These data indicated the importance of SLC25A24/ Slc25a24 in the regulation of body fat mass and adipogenesis, in both humans and mice [105].

\section{Disclosure statements}

All authors have nothing to declare.

\section{Acknowledgements}

We thank Dr. Masataka Shiraki, Dr. Takayuki Hosoi, Dr Yasuyoshi Ouchi, Dr Fumihiko Urano and the researchers in our laboratory for helpful discussion. This work was supported by program from the JSPS, Japan; by Grants-in-Aid from the MHLW, Japan. 


\section{References}

1. Cummings SR, Melton LJ (2002) Epidemiology and outcomes of osteoporotic fractures. Lancet 359: 17611767.

2. Dawson-Hughes B; National Osteoporosis Foundation Guide Committee (2008) A revised clinician's guide to the prevention and treatment of osteoporosis. J Clin Endocrinol Metab 93: 2463-2465.

3. Flicker L, Hopper JL, Rodgers L, Kaymakci B, Green RM, et al. (1995) Bone density determinants in elderly women: a twin study. J Bone Miner Res 10: 1607-1613.

4. Smith DM, Nance WE, Kang KW, Christian JC, Johnston CC Jr (1973) Genetic factors in determining bone mass. J Clin Invest 52: 2800-2808.

5. Young D, Hopper JL, Nowson CA, Green RM, Sherwin AJ, et al. (1995) Determinants of bone mass in 10- to 26-year-old females: a twin study. J Bone Miner Res 10: 558-567.

6. Liu YJ, Zhang L, Papasian CJ, Deng HW (2014) Genome-wide Association Studies for Osteoporosis: A 2013 Update. J Bone Metab 21: 99-116.

7. Urano T, Inoue S (2014) Genetics of osteoporosis. Biochem Biophys Res Commun 452: 287-293.

8. Karakelides H, Nair KS (2005) Sarcopenia of aging and its metabolic impact. Curr Top Dev Biol 68: 123-148.

9. Cruz-Jentoft AJ, Baeyens JP, Bauer JM, Boirie Y, Cederholm T, et al. (2010) Sarcopenia: European consensus on definition and diagnosis: Report of the European Working Group on Sarcopenia in Older People. Age Ageing 39, 412-423.

10. Chen LK, Liu LK, Woo J, Assantachai P, Auyeung TW, et al. (2014) Sarcopenia in Asia: consensus report of the Asian Working Group for Sarcopenia. J Am Med Dir Assoc 15: 95-101.

11. Hsu FC, Lenchik L, Nicklas BJ, Lohman K, Register TC, et al. (2005) Heritability of body composition measured by DXA in the diabetes heart study. Obes Res 13: 312-319.

12. Keen-Kim D, Mathews CA, Reus VI, Lowe TL, Herrera LD, et al. (2006) Overrepresentation of rare variants in a specific ethnic group may confuse interpretation of association analyses. Hum Mol Genet 15: 3324-3328.

13. Lewis CE, McTigue KM, Burke LE, Poirier P, Eckel RH, et al. (2009) Mortality, health outcomes, and body mass index in the overweight range: a science advisory from the American Heart Association. Circulation 119:3263-3271.

14. Stunkard AJ, Foch TT, Hrubec Z (1986) A twin study of human obesity. JAMA 256: 51-54.

15. Maes HH, Neale MC, Eaves LJ (1997) Genetic and environmental factors in relative body weight and human adiposity. Behav Genet 27: 325-351.

16. Pollex RL, Hegele RA (2006) Genetic determinants of the metabolic syndrome. Nat Clin Pract Cardiovasc
Med 3: 482-489.

17. Fall T, Ingelsson E (2014) Genome-wide association studies of obesity and metabolic syndrome. Mol Cell Endocrinol 382: 740-757.

18. Tella SH, Gallagher JC (2014) Prevention and treatment of postmenopausal osteoporosis. J Steroid Biochem Mol Biol 142: 155-170.

19. Nilsson S, Gustafsson JA (2011) Estrogen receptors: therapies targeted to receptor subtypes. Clin Pharmacol Ther 89: 44-55.

20. Lee K, Jessop H, Suswillo R, Zaman G, Lanyon L (2003) Endocrinology: bone adaptation requires oestrogen receptor-alpha. Nature 424: 389.

21. Gennari L, Merlotti D, De Paola V, Calabrò A, Becherini L, et al. (2005) Estrogen receptor gene polymorphisms and the genetics of osteoporosis: a HuGE review. Am J Epidemiol 161: 307-320.

22. Sano M, Inoue S, Hosoi T, Ouchi Y, Emi M, et al. (1995) Association of estrogen receptor dinucleotide repeat polymorphism with osteoporosis. Biochem Biophys Res Commun 217: 378-383.

23. Kobayashi S, Inoue S, Hosoi T, Ouchi Y, Shiraki M, et al. (1996) Association of bone mineral density with polymorphism of the estrogen receptor gene. $J$ Bone Miner Res 11: 306-311.

24. Gennari L, De Paola V, Merlotti D, Martini G, Nuti R (2007) Steroid hormone receptor gene polymorphisms and osteoporosis: a pharmacogenomic review. Expert Opin Pharmacother 8: 537-553.

25. Herrington DM, Vittinghoff E, Lin F, Fong J, Harris F, et al. (2002) Statin therapy, cardiovascular events, and total mortality in the Heart and Estrogen/Progestin Replacement Study (HERS). Circulation 105: 29622967.

26. Iwashita S, Koyama K, Nakamura Y (2001) VNTR sequence on human chromosome 11p15 that affects transcriptional activity. J Hum Genet 46: 717-721.

27. Rivadeneira F, Styrkársdottir U, Estrada K, Halldórsson BV, Hsu YH, et al. (2009) Twenty bone-mineral-density loci identified by large-scale meta-analysis of genomewide association studies. Nat Genet 41: 1199-1206.

28. Richards JB, Kavvoura FK, Rivadeneira F, Styrkársdóttir U, Estrada K, et al. (2009) Collaborative meta-analysis: associations of 150 candidate genes with osteoporosis and osteoporotic fracture. Ann Intern Med 151: 528537.

29. Paternoster L, Lorentzon M, Lehtimäki T, Eriksson J, Kähönen M, et al. (2013) Genetic determinants of trabecular and cortical volumetric bone mineral densities and bone microstructure. PLoS Genet 9: e1003247.

30. Zhang L, Choi HJ, Estrada K, Leo PJ, Li J, et al. (2014) Multistage genome-wide association meta-analyses identified two new loci for bone mineral density. Hum 
Mol Genet 23: 1923-1933.

31. Moayyeri A, Hsu YH, Karasik D, Estrada K, Xiao SM, et al. (2014) Genetic determinants of heel bone properties: genome-wide association meta-analysis and replication in the GEFOS/GENOMOS consortium. Hum Mol Genet 23: 3054-68.

32. MacDonald BT, Tamai K, He X (2009) Wnt/betacatenin signaling: components, mechanisms, and diseases. Dev Cell 17: 9-26.

33. Gong Y, Slee RB, Fukai N, Rawadi G, Roman-Roman $\mathrm{S}$, et al. (2001) Osteoporosis-Pseudoglioma Syndrome Collaborative Group. LDL receptor-related protein 5 (LRP5) affects bone accrual and eye development. Cell 107: 513-523.

34. Boyden LM, Mao J, Belsky J, Mitzner L, Farhi A, et al. (2002) High bone density due to a mutation in LDLreceptor-related protein 5. N Engl J Med 346: 15131521

35. Little RD, Carulli JP, Del Mastro RG, Dupuis J, Osborne $\mathrm{M}$, et al. (2002) A mutation in the LDL receptor-related protein 5 gene results in the autosomal dominant highbone-mass trait. Am J Hum Genet 70: 11-19.

36. Ferrari SL, Deutsch S, Antonarakis SE (2005) Pathogenic mutations and polymorphisms in the lipoprotein receptor-related protein 5 reveal a new biological pathway for the control of bone mass. Curr Opin Lipidol 16: 207-214.

37. Urano T, Shiraki M, Ezura Y, Fujita M, Sekine E, et al. (2004) Association of a single-nucleotide polymorphism in low-density lipoprotein receptor-related protein 5 gene with bone mineral density. $J$ Bone Miner Metab 22: 341-345.

38. Ezura Y, Nakajima T, Urano T, Sudo Y, Kajita M, et al. (2007) Association of a single-nucleotide variation (A1330V) in the low-density lipoprotein receptorrelated protein 5 gene (LRP5) with bone mineral density in adult Japanese women. Bone 40: 997-1005.

39. Mizuguchi T, Furuta I, Watanabe Y, Tsukamoto K, Tomita H, et al. (2004) LRP5, low-density-lipoproteinreceptor-related protein 5 , is a determinant for bone mineral density. J Hum Genet 49: 80-86.

40. Koay MA, Woon PY, Zhang Y, Miles LJ, Duncan EL, et al. (2004) Influence of LRP5 polymorphisms on normal variation in BMD. J Bone Miner Res 19: 1619-1627.

41. Bollerslev J, Wilson SG, Dick IM, Islam FM, Ueland T, et al. (2005) LRP5 gene polymorphisms predict bone mass and incident fractures in elderly Australian women. Bone 36: 599-606.

42. Ferrari SL, Deutsch S, Baudoin C, Cohen-Solal M, Ostertag A, et al. (2005) LRP5 gene polymorphisms and idiopathic osteoporosis in men. Bone 37: 770-775.

43. van Meurs JB, Rivadeneira F, Jhamai M, Hugens W, Hofman A, et al. (2006) Common genetic variation of the low-density lipoprotein receptor-related protein 5 and 6 genes determines fracture risk in elderly white men. J Bone Miner Res 21: 141-150.

44. Saarinen A, Välimäki VV, Välimäki MJ, Löyttyniemi E, Auro K, et al. (2007) The A1330V polymorphism of the low-density lipoprotein receptor-related protein 5 gene (LRP5) associates with low peak bone mass in young healthy men. Bone 40: 1006-1012.

45. Xiong DH, Lei SF, Yang F, Wang L, Peng YM, et al. (2007) Low-density lipoprotein receptor-related protein 5 (LRP5) gene polymorphisms are associated with bone mass in both Chinese and whites. J Bone Miner Res 22: 385-393.

46. Giroux S, Elfassihi L, Cardinal G, Laflamme N, Rousseau F (2007) LRP5 coding polymorphisms influence the variation of peak bone mass in a normal population of French-Canadian women. Bone 40: 12991307.

47. van Meurs JB, Trikalinos TA, Ralston SH, Balcells S, Brandi ML, et al. (2008) Large-scale analysis of association between LRP5 and LRP6 variants and osteoporosis. JAMA 299: 1277-1290.

48. Richards JB, Rivadeneira F, Inouye M, Pastinen TM, Soranzo N, et al. (2008) Bone mineral density, osteoporosis, and osteoporotic fractures: a genome-wide association study. Lancet 371: 1505-1512.

49. Agueda L, Bustamante M, Jurado S, Garcia-Giralt N, Ciria M, et al. (2008) A haplotype-based analysis of the LRP5 gene in relation to osteoporosis phenotypes in Spanish postmenopausal women. J Bone Miner Res 23: 1954-1963.

50. Urano T, Shiraki M, Usui T, Sasaki N, Ouchi Y, et al. (2009) A1330V variant of the low-density lipoprotein receptor-related protein 5 (LRP5) gene decreases Wnt signaling and affects the total body bone mineral density in Japanese women. Endocr J 56: 625-631.

51. Lee YH, Woo JH, Choi SJ, Ji JD, Song GG (2009) Association between the A1330V polymorphism of the low-density lipoprotein receptor-related protein 5 gene and bone mineral density: a meta-analysis. Rheumatol Int 29: 539-544.

52. Ferrari SL, Deutsch S, Choudhury U, Chevalley T, Bonjour JP, et al. (2004) Polymorphisms in the lowdensity lipoprotein receptor-related protein 5 (LRP5) gene are associated with variation in vertebral bone mass, vertebral bone size, and stature in whites. Am J Hum Genet 74: 866-875.

53. Koh JM, Jung MH, Hong JS, Park HJ, Chang JS, et al. (2004) Association between bone mineral density and LDL receptor-related protein 5 gene polymorphisms in young Korean men. J Korean Med Sci 19: 407-412.

54. Zhang ZL, Qin YJ, He JW, Huang QR, Li M, et al. (2005) Association of polymorphisms in low-density lipoprotein receptor-related protein 5 gene with bone mineral density in postmenopausal Chinese women. Acta Pharmacol Sin 26: 1111-1116.

55. Urano T, Shiraki M, Narusawa K, Usui T, Sasaki N, et 
al. (2007) Q89R polymorphism in the LDL receptorrelated protein 5 gene is associated with spinal osteoarthritis in postmenopausal Japanese women. Spine 32: 25-29.

56. Clarke M, Ward M, Strain JJ, Hoey L, Dickey W, et al. (2014) B-vitamins and bone in health and disease: the current evidence. Proc Nutr Soc 73: 330-339.

57. Reilly R, McNulty H, Pentieva K, Strain JJ, Ward M (2014) MTHFR 677TT genotype and disease risk: is there a modulating role for B-vitamins? Proc Nutr Soc 73: 47-56.

58. Devoto M, Specchia C, Li HH, Caminis J, Tenenhouse A, et al. (2001) Variance component linkage analysis indicates a QTL for femoral neck bone mineral density on chromosome 1p36. Hum Mol Genet 10: 2447-2452.

59. Spotila LD, Rodriguez H, Koch M, Tenenhouse HS, Tenenhouse A, et al. (2003) Association analysis of bone mineral density and single nucleotide polymorphisms in two candidate genes on chromosome $1 \mathrm{p} 36$. Calcif Tissue Int 73: 140-146.

60. Gjesdal CG, Vollset SE, Ueland PM, Refsum H, Meyer $\mathrm{HE}$, et al. (2007) Plasma homocysteine, folate, and vitamin B 12 and the risk of hip fracture: the hordaland homocysteine study. J Bone Miner Res 22: 747-756.

61. van Meurs JB, Dhonukshe-Rutten RA, Pluijm SM, van der Klift M, de Jonge R, et al. (2004) Homocysteine levels and the risk of osteoporotic fracture. $N$ Engl J Med 350: 2033-2041.

62. McLean RR, Jacques PF, Selhub J, Tucker KL, Samelson EJ, et al. (2004) Homocysteine as a predictive factor for hip fracture in older persons. $N \mathrm{Engl} \mathrm{J}$ Med 350: 2042-2049.

63. Lubec B, Fang-Kircher S, Lubec T, Blom HJ, Boers GH (1996) Evidence for McKusick's hypothesis of deficient collagen cross-linking in patients with homocystinuria. Biochim Biophys Acta 1315: 159-162.

64. Saito M, Fujii K, Marumo K (2006) Degree of mineralization-related collagen crosslinking in the femoral neck cancellous bone in cases of hip fracture and controls. Calcif Tissue Int 79: 160-168.

65. Herrmann M, Peter Schmidt J, Umanskaya N, Wagner A, Taban-Shomal O, et al. (2007) The role of hyperhomocysteinemia as well as folate, vitamin $\mathrm{B}(6)$ and $\mathrm{B}(12)$ deficiencies in osteoporosis: a systematic review. Clin Chem Lab Med 45: 1621-1632.

66. Bai R, Liu W, Zhao A, Zhao Z, Jiang D (2013) Quantitative assessment of the associations between MTHFR C677T and A1298C polymorphisms and risk of fractures: a meta-analysis. Mol Biol Rep 40: 24192430 .

67. Shiraki M, Urano T, Kuroda T, Saito M, Tanaka S, et al. (2008) The synergistic effect of bone mineral density and methylenetetrahydrofolate reductase (MTHFR) polymorphism (C677T) on fractures. J Bone Miner Metab 26: 595-602.
68. Urano T, Shiraki M, Saito M, Sasaki N, Ouchi Y, et al. (2014) Polymorphism of SLC25A32, the folate transporter gene, is associated with plasma folate levels and bone fractures in Japanese postmenopausal women. Geriatr Gerontol Int 14: 942-946.

69. Titus SA, Moran RG (2000) Retrovirally mediated complementation of the glyB phenotype. Cloning of a human gene encoding the carrier for entry of folates into mitochondria. J Biol Chem 275: 36811-36817.

70. McCarthy EA, Titus SA, Taylor SM, Jackson-Cook C, Moran RG (2004) A mutation inactivating the mitochondrial inner membrane folate transporter creates a glycine requirement for survival of chinese hamster cells. J Biol Chem 279: 33829-33836.

71. Kiel DP, Demissie S, Dupuis J, Lunetta KL, Murabito JM, et al. (2007) Genome-wide association with bone mass and geometry in the Framingham Heart Study. BMC Med Genet 8: S14.

72. Styrkarsdottir U, Halldorsson BV, Gretarsdottir S, Gudbjartsson DF, Walters GB, et al. (2008) Multiple genetic loci for bone mineral density and fractures. $N$ Engl J Med 358: 2355-2365.

73. Styrkarsdottir U, Halldorsson BV, Gretarsdottir S, Gudbjartsson DF, Walters GB, et al. (2009) New sequence variants associated with bone mineral density. Nat Genet 41: 15-17.

74. Xiong DH, Liu XG, Guo YF, Tan LJ, Wang L, et al. (2009) Genome-wide association and follow-up replication studies identified ADAMTS18 and TGFBR3 as bone mass candidate genes in different ethnic groups. Am J Hum Genet 84: 388-398.

75. Cho YS, Go MJ, Kim YJ, Heo JY, Oh JH, et al. (2009) A large-scale genome-wide association study of Asian populations uncovers genetic factors influencing eight quantitative traits. Nat Genet 41: 527-534.

76. Kung AW, Xiao SM, Cherny S, Li GH, Gao Y, et al. (2010) Association of JAG1 with bone mineral density and osteoporotic fractures: a genome-wide association study and follow-up replication studies. Am J Hum Genet 86: 229-239.

77. Urano T, Shiraki M, Usui T, Sasaki N, Ouchi Y, et al. (2010) Identification of non-synonymous polymorphisms in the WDSOF1 gene as novel susceptibility markers for low bone mineral density in Japanese postmenopausal women. Bone 47: 636-642.

78. Kou I, Takahashi A, Urano T, Fukui N, Ito H, et al. (2011) Common variants in a novel gene, FONG on chromosome 2q33.1 confer risk of osteoporosis in Japanese. PLoS One 6: e19641.

79. Urano T, Shiraki M, Yagi H, Ito M, Sasaki N, et al. (2012) GPR98/Gpr98 gene is involved in the regulation of human and mouse bone mineral density. J Clin Endocrinol Metab 97: E565-574.

80. Estrada K, Styrkarsdottir U, Evangelou E, Hsu YH, Duncan EL, et al. (2012) Genome-wide meta-analysis 
identifies 56 bone mineral density loci and reveals 14 loci associated with risk of fracture. Nat Genet 44: 491501.

81. Medina-Gomez C, Kemp JP, Estrada K, Eriksson J, Liu J, et al. (2012) Meta-analysis of genome-wide scans for total body BMD in children and adults reveals allelic heterogeneity and age-specific effects at the WNT16 locus. PLoS Genet 8: e1002718.

82. Zheng HF, Tobias JH, Duncan E, Evans DM, Eriksson J, et al. (2012) WNT16 influences bone mineral density, cortical bone thickness, bone strength, and osteoporotic fracture risk. PLoS Genet 8: e1002745.

83. Richards JB, Zheng HF, Spector TD (2012) Genetics of osteoporosis from genome-wide association studies: advances and challenges. Nat Rev Genet 13: 576-588.

84. Trouvin AP, Goëb V (2010) Receptor activator of nuclear factor- $\kappa \mathrm{B}$ ligand and osteoprotegerin: maintaining the balance to prevent bone loss. Clin Interv Aging 5: 345-354.

85. Miyazaki T, Tokimura F, Tanaka S (2014) A review of denosumab for the treatment of osteoporosis. Patient Prefer Adherence 8: 463-471.

86. Rossini M, Gatti D, Adami S (2013) Involvement of $\mathrm{WNT} / \beta$-catenin signaling in the treatment of osteoporosis. Calcif Tissue Int 93: 121-132.

87. Giguere PM, Kroeze WK, Roth BL (2014) Tuning up the right signal: chemical and genetic approaches to study GPCR functions. Curr Opin Cell Biol 27: 51-55.

88. Hansen RD, Raja C, Aslani A, Smith RC, Allen BJ (1999) Determination of skeletal muscle and fat-free mass by nuclear and dual-energy x-ray absorptiometry methods in men and women aged 51-84 y (1-3). Am J Clin Nutr 70: 228-233.

89. Liu XG, Tan LJ, Lei SF, Liu YJ, Shen H, et al. (2009) Genome-wide association and replication studies identified TRHR as an important gene for lean body mass. Am J Hum Genet 84: 418-423.

90. Hai R, Pei YF, Shen H, Zhang L, Liu XG, et al. (2012) Genome-wide association study of copy number variation identified gremlin 1 as a candidate gene for lean body mass. J Hum Genet 57: 33-37.

91. Guo YF, Zhang LS, Liu YJ, Hu HG, Li J, et al. (2013) Suggestion of GLYAT gene underlying variation of bone size and body lean mass as revealed by a bivariate genome-wide association study. Hum Genet 132: 189199.

92. Ran S, Liu YJ, Zhang L, Pei Y, Yang TL, et al. (2014) Genome-wide association study identified copy number variants important for appendicular lean mass. PLoS One 9: e89776.
93. Urano T, Shiraki M, Sasaki N, Ouchi Y, Inoue S (2014) Large-scale analysis reveals a functional single-nucleotide polymorphism in the 5'-flanking region of PRDM16 gene associated with lean body mass. Aging Cell 13: 739-743.

94. Seale P, Bjork B, Yang W, Kajimura S, Chin S, et al. (2008) PRDM16 controls a brown fat/skeletal muscle switch. Nature 454: 961-967.

95. Scott LJ, Mohlke KL, Bonnycastle LL, Willer CJ, Li Y, et al. (2007) A genome-wide association study of type 2 diabetes in Finns detects multiple susceptibility variants. Science 316: 1341-1345.

96. Scuteri A, Sanna S, Chen WM, Uda M, Albai G, et al. (2007) Genome-wide association scan shows genetic variants in the FTO gene are associated with obesity-related traits. PLoS Genet 3: e115.

97. Hinney A, Nguyen TT, Scherag A, Friedel S, Brönner G, et al. (2007) Genome wide association (GWA) study for early onset extreme obesity supports the role of fat mass and obesity associated gene (FTO) variants. PLoS One 2: e1361.

98. Tung YC, Yeo GS, O’Rahilly S, Coll AP (2014) Obesity and FTO: Changing Focus at a Complex Locus. Cell Metab 20: 710-718.

99. Adamski J (2012) Genome-wide association studies with metabolomics. Genome Med 4: 34.

100. Lu Y, Loos RJ (2013) Obesity genomics: assessing the transferability of susceptibility loci across diverse populations. Genome Med 5: 55.

101. Kilpeläinen TO, Zillikens MC, Stančákova A, Finucane FM, Ried JS, et al. (2011) Genetic variation near IRS1 associates with reduced adiposity and an impaired metabolic profile. Nat Genet 43: 753-760.

102. Berndt SI, Gustafsson S, Mägi R, Ganna A, Wheeler E, et al. (2013) Genome-wide meta-analysis identifies 11 new loci for anthropometric traits and provides insights into genetic architecture. Nat Genet 45: 501-512.

103. Basile KJ, Johnson ME, Xia Q, Grant SF (2014) Genetic Susceptibility to Type 2 Diabetes and Obesity: Follow-Up of Findings from Genome-Wide Association Studies. Int J Endocrinol 2014: 769671.

104. Okada Y, Kubo M, Ohmiya H, Takahashi A, Kumasaka $\mathrm{N}$, et al. (2012) Common variants at CDKAL1 and KLF9 are associated with body mass index in east Asian populations. Nat Genet 44: 302-306.

105. Urano T, Shiraki M, Sasaki N, Ouchi Y, Inoue S (2015) SLC25A24 as a novel susceptibility gene for low fat mass in humans and mice. J Clin Endocrinol Metab 100: E655-663. 